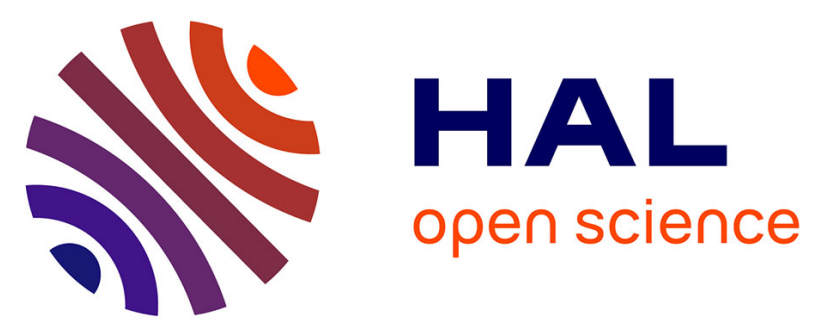

\title{
The demand-pull approach to business model innovation through product-service systems: A case study
}

Martha Orellano, Christine Lambey-Checchin, Khaled Medini, Gilles Neubert

\section{To cite this version:}

Martha Orellano, Christine Lambey-Checchin, Khaled Medini, Gilles Neubert. The demand-pull approach to business model innovation through product-service systems: A case study. IFIP International Conference on Advances in Production Management Systems (APMS), Aug 2018, Seoul, South Korea. pp.201-210, 10.1007/978-3-319-99704-9_25 . emse-01885109

\section{HAL Id: emse-01885109 \\ https://hal-emse.ccsd.cnrs.fr/emse-01885109}

Submitted on 25 Jun 2019

HAL is a multi-disciplinary open access archive for the deposit and dissemination of scientific research documents, whether they are published or not. The documents may come from teaching and research institutions in France or abroad, or from public or private research centers.
L'archive ouverte pluridisciplinaire HAL, est destinée au dépôt et à la diffusion de documents scientifiques de niveau recherche, publiés ou non, émanant des établissements d'enseignement et de recherche français ou étrangers, des laboratoires publics ou privés. 


\title{
The demand-pull approach to business model innovation through product-service systems: a case study
}

\author{
Martha Orellano ${ }^{1(\bowtie)}$, Christine Lambey-Checchin ${ }^{2}$, Khaled Medini $^{3}$ \\ and Gilles Neubert ${ }^{4}$ \\ ${ }^{1}$ Ecole Nationale Supérieure des Mines de Saint-Etienne, CNRS, UMR 5600 EVS, F-42023 \\ martha.orellano@emse.fr \\ ${ }^{2}$ Université Clermont Auvergne, EA3849 CRCGM, F-63008 \\ ${ }^{3}$ Ecole Nationale Supérieure des Mines de Saint-Etienne, CNRS, UMR 6158 LIMOS, F-42023 \\ ${ }^{4}$ emlyon business school, CNRS, UMR 5600 EVS, F-42009
}

\begin{abstract}
Industry is facing a deep transformation of the modes of production and consumption, resulting in a shift from product-centric practices towards sustainable and customer-oriented ones. In this context, Product-Service Systems (PSS) exhibit the potential for innovative and customer oriented value propositions. To take full advantage of PSS, it is essential to design suitable business models enabling an alignment of the processes, products and services to customer needs. Innovation Management is an important literature stream contributing to understand the business model transformation by differentiating between two main approaches of innovation: technology-push and demand-pull. Until now, little attention has been put in the demand-pull approach for business model innovation. The central question this paper addresses is: How does the demandpull approach for the design of a PSS value proposition affects the whole business model of a company? To answer this question a literature review is a carried out, and then a research-intervention methodology is applied to a real case.
\end{abstract}

Keywords: Business Models, Demand-pull Innovation, Product-Service Systems, Case Study.

\section{$1 \quad$ Introduction}

Currently, manufacturing industry is shifting towards Product-Service Systems (PSS), considered as innovative value propositions, which are narrowly concerned with the customer integration and sustainability issues [1]. PSS are defined as the bundle of products and services capable to fulfill the customer needs along the time, improving profitability and competitiveness for the provider through services provision [1]. One of the main challenges for the adoption of PSS is the transformation of the whole business model. Innovation Management is an important research stream contributing to understand the business model transformation and the effects inside and outside the company boundaries. Literature differentiates between two main approaches of innovation: technology-push and demand-pull, both influencing the business model design. Technology-push approach highlights the key role of science and technology as the 
trigger of innovation, while demand-pull approach argues that the innovation is the direct result of the customer demand. Even if in practice the demand-pull approach seems to be well understood, in literature little attention has been put in it [2], [3].Taking into account such a lack on the literature, this paper focus on exploring the influence of the demand-pull approach in business models for innovative value propositions like PSS. The central question this paper addresses is: How does the pull-demand approach for the design of a PSS value proposition affect the whole business model of a company? In particular, this paper aims at exploring how the organizational structure, the roles of actors and the value creation processes are transformed due to the adoption of a PSS value proposition triggered by the customer. To answer this question, a literature review is a carried out to understand the demand-based innovation of business models. Then a research-intervention methodology is applied in order to explore the influence of demand-pull innovation on the organizational structure, actors' roles, and PSS value creation process.

The structure of the paper is as follows: section 2 explains briefly the state of the art and presents a conceptual framework of the PSS business model, with an emphasis on the demand-pull innovation. Section 3 presents the design of the research and section 4 develops a single case study in a large-sized company carrying out a PSS project. Finally, conclusions and research perspectives are drawn in section 5 .

\section{The Demand-pull approach to business models innovation}

\subsection{The demand-pull approach to innovation}

Innovation is traditionally defined as the set of technical, industrial and commercial operations that enable organizations to perform efficiently their economic activities [4]. Recent literature considers innovation as the iterative process of learning, which needs intensive collaboration between a broader set of actors to improve any process [5]. Given how extensive this concept is, innovation has been studied from two principal approaches: Technology-push and Demand-pull (also called Marked-pull) [4] (Fig. 1). Technology-push approach highlights the key role of science and technology as the triggers of innovation, originated and developed from the provider capabilities [3]. Demand-pull approach, in contrast, argues that the innovation is the result of the market demand, which directly triggers the development of innovations and the principal actors are those involved in customer-provider relationships [4], [7]. In a technology-push innovation, the provider decides what to innovate in products, services and processes regarding its capabilities, taking the risk of developing an unsaleable offer. In this logic, the provider needs high investment in technology and internal learning, while the customer has mainly a secondary role during the whole development process [2]. In a demand-pull innovation, the customer defines its needs in terms of products, services and processes and looks for providers capable to develop it while collaborating with a set of actors. In this logic, the provider must be reactive and manage the integration of the customer into the whole process, the risk is shared between the set of actors and the customer has a main role of coordinator. With the evolution of markets, technologies, human behavior and policies, the approaches to innovation have evolved towards more 
systemic models, adopting elements from both technology-push and demand-pull perspectives [5], [6]. Both approaches to innovation seems to be interdependent, where technology is a key resource and demand is the key driver guiding towards the right direction of economic growth [3]. However, the impacts of these innovation triggers on the business model are different [2], even if, in both cases, providers and customers must adapt their business models to the development of the innovative offers.

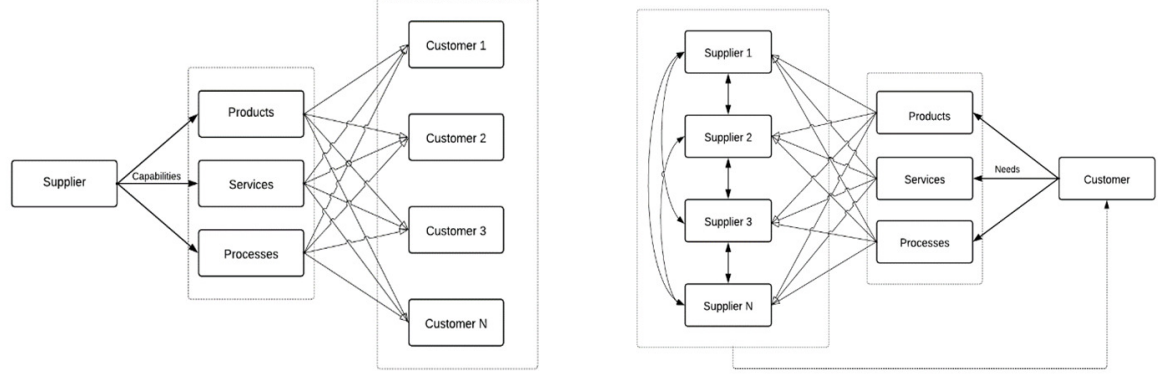

Fig. 1. Technology-push (left) and Demand-pull (right) approaches to innovation.

\subsection{Business model innovation}

Chesbrough [7] defines the business model as the heuristic logic of a company that connects the technical potential with the creation of value. They consider that innovation is not just about technology, but spans over the entire business model, which must be strictly aligned with the market [7]. Over the last decade, the research on business model has been associated to innovation in many ways, for instance, innovative revenue models (e.g. free business models, shared economy, low-cost offerings), the transformation of the value creation mindset (e.g. Service-Dominant Logic) and collaborating with external knowledge partners (open innovation) [7]-[9]. Several authors agree that the main challenge to innovate in business models is the conflict with the already established model, which means the resources, activities, actors, and the set of conventional practices [7], [8], [10]. Recent literature proposes the innovation in business model through the transformation of the value creation mindset, adopting a multi-actor and multidimensional approach [11]. One of the literature streams influencing the change of the value creation mindset is the SDL [9]. SDL states that the value is cocreated by the provider and the customer, highlighting the primacy of value creation during the use phase, in which the value beneficiary is exclusively the customer. Beside customer-centric approach of SDL, recent authors consider that a business model encompasses environmental, social and economic values, co-created by and for a broader set of actors in a business ecosystem. For instance, Tukker et al. [12] associate business model innovation to disruptive innovative value propositions that seeks to respond to sustainability issues with a customer orientation. These authors argue that the radical innovation in business models is the most efficient way for achieving sustainability while improving competitiveness [10], [12]. In this sense, Bocken et al. [13] propose some sustainable business model archetypes, which are able to create value while respecting the environment and society. PSS is one of the considered business models archetypes, and it is typically defined as the bundle of products and services capable to 
fulfill customer needs along the time, improving profitability and competitiveness while seeking at reducing environmental and social impacts [1].

\subsection{Conceptual framework for PSS business models innovation}

This section reports on a conceptual framework for PSS business models, which takes into account the lifecycle perspective intrinsic into PSS offerings (Fig. 2). This conceptual framework aims at explaining the business model as a central element of the economic activities, which must be linked to the environmental and social spheres during the whole lifecycle of a given offer [10], [11], [14]. The business model shapes the interaction between socio-economic and politic actors, involving customers, stakeholders, partners, competitors, public institutions and government, which could be enablers of innovation initiatives [8], [11], [14].

The elements of the proposed framework are defined as follows: Value proposition relates to the offer that is developed to fulfill a specific need of the customer, approached by a PSS type [15]. Value structure refers to the set of actors involved in the required processes and the relationships between them. Value performance refers to the evaluation of the value created from the business activity in each stage of the lifecycle. These elements of the business model are impacted by the ideas of innovation engendered from the customer side [8]. Next section illustrates this impact through a case study.

\begin{tabular}{|c|c|c|c|c|c|c|c|c|}
\hline \multirow[b]{2}{*}{$\begin{array}{c}\text { Sub-process } \\
\text { Business model element }\end{array}$} & \multicolumn{4}{|c|}{ Beginning of life (BOL) } & \multicolumn{2}{|c|}{ Middle of life (MOL) } & \multicolumn{2}{|c|}{ End of life (EOL) } \\
\hline & Conception & Testing & Production & Distribution & Use & Maintenance & Tacking back & Disposal \\
\hline Value structure & \multicolumn{4}{|c|}{ Actors (resources, activities, relationships) } & \multicolumn{2}{|c|}{$\begin{array}{l}\text { Actors (resources, } \\
\text { activities, relationships) }\end{array}$} & \multicolumn{2}{|c|}{$\begin{array}{l}\text { Actors (resources, activities, } \\
\text { relationships) }\end{array}$} \\
\hline Value proposition & \multicolumn{4}{|c|}{ Product oriented PSS } & \multicolumn{2}{|c|}{$\begin{array}{c}\text { Service or result oriented } \\
\text { PSS }\end{array}$} & \multicolumn{2}{|c|}{ Service or result oriented PSS } \\
\hline \multirow[t]{2}{*}{ Value performance } & \multicolumn{4}{|c|}{$\begin{array}{l}\text { Dimensions: Environmental, social, relational and } \\
\text { economics. }\end{array}$} & \multicolumn{2}{|c|}{$\begin{array}{l}\text { Dimensions: } \\
\text { Environmental, social, } \\
\text { relational and economics. }\end{array}$} & \multicolumn{2}{|c|}{$\begin{array}{l}\text { Dimensions: Environmental, social, } \\
\text { relational and economics. }\end{array}$} \\
\hline & \multicolumn{8}{|c|}{$\begin{array}{c}\text { Methods to evaluate value performance: } \\
\text { LCC (Lifecycle Costing), LCA (Lifecycle Assessment), SLCA (Social Lifecycle Assessment), } \\
\text { Relational metrics: PEAK Collaborative index }\end{array}$} \\
\hline
\end{tabular}

Fig. 2. Conceptual framework of business models for Product-Service Systems (PSS) [16].

\section{Research Design}

\subsection{Case study description}

For this research, the case study method is used to generate in-depth insights about the effects of the demand-pull approach to innovation on the business model of a selected company. Using a case study contributes to addressing the lack of empirical data about business model innovation from a demand-pull approach, specifically, addressing PSS contexts [8]. The case study is conducted within a large-sized company, which we will call $\mathrm{C} 1$, for confidentiality reasons. $\mathrm{C} 1$ business activity is the production and distribution of energy. One of the most important support activities of the company is the provision of safety clothing for all its employees. Currently, the safety clothes belong to the employees who are fully responsible for their usage, maintenance and end of life. 
This process introduces a lack of control by $\mathrm{C} 1$ of some phases of the safety clothes lifecycle. To address this problem, $\mathrm{C} 1$ launched an innovation project to redefine the offer in collaboration with its key suppliers. The objective of the project is to move from a product purchasing-based offer towards a PSS-based offer considering a lifecycle perspective. For the new offer, $\mathrm{C} 1$ wants to have available safety clothes all the time for the employees, while guarantying the traceability during the entire lifecycle with the lowest possible environmental and social impacts. This project represents a clear demand-pull innovation, where the customer $(\mathrm{C} 1)$ introduces the innovation and coordinates all the actors to achieve the objectives.

\subsection{Research-intervention methodology}

The collaboration with $\mathrm{C} 1$ takes place in a 2 years project, which started in October 2017. The project is structured in three main phases: i) Diagnostic of the current business model, ii) Proposal of the future business model and iii) Transformation of the purchasing strategy. By the time this paper is written, the project is at an early development stage (phase i), whose objective is to give some insights about the current business model and the key elements for the transformation. The methodology during the diagnostic phase is as follows:

a. Research preparation: Literature review to define the business model elements and the PSS characteristics. Based on literature elements, we structured the interview guides, one model for the internal actors (inside $\mathrm{C} 1$ ) and another one for the external actors (outside $\mathrm{C} 1$ ).

b. Intervention with internal actors: We tested and validated the interview guides with the employees from the purchasing department. Then, a workshop was conducted with the employees from the following departments: Human Resources, Purchasing, Prescription, Research \& Development and Sustainable Development. 12 semi-directive interviews were conducted with these employees, which include directors, managers and operative employees.

c. Intervention with external actors: A workshop was conducted with the contractors and potential providers, from confection, transportation, maintenance (washing) and end of life treatment. 7 semi-directive interviews were conducted with the providers, which include commercial managers and CEOs.

d. Diagnostic construction: We made a lexical analysis of the interviews using the software ALCESTE to exploit the data.

\section{$4 \quad$ Results}

Based on the insights from the literature, $\mathrm{C} 1$ is clearly positioned in a demand-pull innovation scenario, where the customer is both the trigger of innovation and the main coordinator of the business model transformation (regarding internal and the external value chains). In the following, the case is described through the detailed framework of the PSS business model (Fig. 2). Each element of the business model is instantiated in the current model and in the prospective model as explained by the set of internal and 
external actors interviewed. Table 1 describes in detail the current $\mathrm{C} 1$ business model and Table 2 illustrates the different transformations observed from the demand-pull innovation induced with the PSS value proposition.

Table 1. Current business model of company C1.

\begin{tabular}{|c|c|c|c|c|}
\hline $\begin{array}{c}\text { Business model } \\
\text { elements }\end{array}$ & & Beginning of life (BOL) & $\begin{array}{l}\text { Middle of life } \\
\text { (MOL) }\end{array}$ & End of life (EOL) \\
\hline $\begin{array}{l}\text { Value } \\
\text { proposition }\end{array}$ & \multicolumn{2}{|c|}{$\begin{array}{l}\text { Annual dotation of safety clothes follow- } \\
\text { ing high security and image standards, } \\
\text { short lead- time and at the lowest possi- } \\
\text { ble cost. }\end{array}$} & N/A & N/A \\
\hline \multirow{2}{*}{$\begin{array}{l}\text { Value structure } \\
\text { (actors, } \\
\text { resources, } \\
\text { activities) }\end{array}$} & 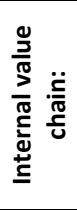 & $\begin{array}{l}\text { - Central role of the prescriber } \\
\text { as the internal customer } \\
\text { - Organization by "silos" } \\
\text { - Purchaser dependent on the } \\
\text { prescriber and providers } \\
\text { - High privacy of internal data. }\end{array}$ & $\begin{array}{l}\text { - High level of re- } \\
\text { sponsibility of the } \\
\text { users about the } \\
\text { clothes use and } \\
\text { maintenance. }\end{array}$ & $\begin{array}{l}\text { - High level of re- } \\
\text { sponsibility of the } \\
\text { users about the } \\
\text { clothes disposal. }\end{array}$ \\
\hline & 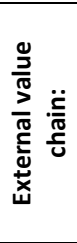 & $\begin{array}{l}\text { - Transactional customer-pro- } \\
\text { vider relationships } \\
\text { - High privacy of own data } \\
\text { - Internalization of economic } \\
\text { risks } \\
\text { - Risk of market monopoliza- } \\
\text { tion. }\end{array}$ & $\begin{array}{l}\text { - Productive part- } \\
\text { nership relation- } \\
\text { ships } \\
\text { - High privacy of } \\
\text { own data }\end{array}$ & N/A \\
\hline $\begin{array}{c}\text { Value } \\
\text { performance }\end{array}$ & \multicolumn{2}{|c|}{$\begin{array}{l}\text { - High economic expenses linked to the } \\
\text { annual dotation } \\
\text { - High water and energy consumption in } \\
\text { the production and safety clothes } \\
\text { (linked to use of cotton fiber). }\end{array}$} & $\begin{array}{l}\text { - Uncontrolled wa- } \\
\text { ter and energy } \\
\text { consumption in } \\
\text { the washing pro- } \\
\text { cess of the safety } \\
\text { clothes. }\end{array}$ & $\begin{array}{l}\text { - Uncontrolled } \\
\text { Waste generation } \\
\text { - Degradation of } \\
\text { the company's } \\
\text { image. }\end{array}$ \\
\hline
\end{tabular}

Table 2. Effects of the demand-pull innovation on the business model of company C1.

\begin{tabular}{|c|c|c|c|c|}
\hline \multirow{2}{*}{$\begin{array}{c}\text { Business } \\
\text { model } \\
\text { elements } \\
\\
\text { Value } \\
\text { proposition }\end{array}$} & \multicolumn{2}{|r|}{ Beginning of life (BOL) } & $\begin{array}{l}\text { Middle of life } \\
\text { (MOL) }\end{array}$ & End of life (EOL) \\
\hline & $\begin{array}{l}\text { Per } \\
\text { clot } \\
\text { curi }\end{array}$ & $\begin{array}{l}\text { manently availability of safety } \\
\text { hes, which incorporates high se- } \\
\text { ity standards. }\end{array}$ & $\begin{array}{l}\text { Washing and } \\
\text { maintenance pro- } \\
\text { cesses with the low- } \\
\text { est possible envi- } \\
\text { ronmental and so- } \\
\text { cial impacts. }\end{array}$ & $\begin{array}{l}\text { Management of re- } \\
\text { manufacturing/ re- } \\
\text { using/ recycling pro- } \\
\text { cesses with the low- } \\
\text { est possible environ- } \\
\text { mental and social im- } \\
\text { pacts. }\end{array}$ \\
\hline $\begin{array}{l}\text { Value } \\
\text { structure } \\
\text { (actors, } \\
\text { resources, } \\
\text { activities) }\end{array}$ & 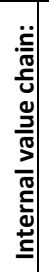 & $\begin{array}{l}\text { - Collaborative organization } \\
\text { - Empowerment of the pur- } \\
\text { chaser as the key coordinator } \\
\text { between internal actors and } \\
\text { providers } \\
\text { - Information sharing } \\
\text { - Collaboration with the trade } \\
\text { unions. }\end{array}$ & $\begin{array}{l}\text { - Responsibility of } \\
\text { employees about } \\
\text { the correct use of } \\
\text { safety clothes } \\
\text { - Information shar- } \\
\text { ing. }\end{array}$ & $\begin{array}{l}\text { - Intensive infor- } \\
\text { mation sharing } \\
\text { - Strategic percep- } \\
\text { tion of the waste. }\end{array}$ \\
\hline
\end{tabular}




\begin{tabular}{|c|c|c|c|c|}
\hline & 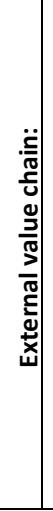 & $\begin{array}{l}\text { - Collaboration with other pur- } \\
\text { chaser companies to rich high } \\
\text { demand levels } \\
\text { - Collaboration with other actors } \\
\text { of the value chain to achieve } \\
\text { the set of criteria in the value } \\
\text { proposition } \\
\text { - Long-term partnerships } \\
\text { - High responsibility on the en- } \\
\text { tire lifecycle of the offer } \\
\text { - Possibility to new providers to } \\
\text { enter to the market } \\
\text { - Risk of high customization and } \\
\text { limited marketability of the of- } \\
\text { fer. }\end{array}$ & $\begin{array}{l}\text { - Intensive infor- } \\
\text { mation sharing } \\
\text { - Possibility to new } \\
\text { providers to enter } \\
\text { to the market } \\
\text { - High responsibility } \\
\text { on the entire } \\
\text { lifecycle of the of- } \\
\text { fer. }\end{array}$ & $\begin{array}{l}\text { - Intensive infor- } \\
\text { mation sharing } \\
\text { - Possibility to new } \\
\text { providers to enter } \\
\text { to the market } \\
\text { - High responsibility } \\
\text { on the entire lifecy- } \\
\text { cle of the offer. }\end{array}$ \\
\hline $\begin{array}{c}\text { Value } \\
\text { performance }\end{array}$ & \multicolumn{2}{|r|}{$\begin{array}{l}\text { - Economic savings linked to the re- } \\
\text { duction of the material consump- } \\
\text { tion (purchasing availability and not } \\
\text { physical products) } \\
\text { - Economic risk sharing } \\
\text { - Reduction of water and energy con- } \\
\text { sumption linked to the use of eco- } \\
\text { friendly fibers. }\end{array}$} & $\begin{array}{l}\text { - Economic risk shar- } \\
\text { ing } \\
\text { - Reduction of water } \\
\text { and energy con- } \\
\text { sumption linked to } \\
\text { the control of the } \\
\text { washing process } \\
\text { - Guarantee of em- } \\
\text { ployees security } \\
\text { and comfort. }\end{array}$ & $\begin{array}{l}\text { - Remanufacturing, } \\
\text { reusing and recy- } \\
\text { cling in the end of } \\
\text { life } \\
\text { - Contracting with lo- } \\
\text { cal companies and } \\
\text { charity organiza- } \\
\text { tions. }\end{array}$ \\
\hline
\end{tabular}

The analyzed sample of internal and external actors is diverse regarding their profiles, for instance, operative employees, managers and CEOs from different departments of the implied organizations. The study reveals interesting points of evolution, relating particularly to the collaboration and the integration of sustainability issues into the PSS value proposition. Furthermore, some specific roles within the internal value chain of $\mathrm{C} 1$ are radically transformed, for instance, the prescriber and the purchaser changed their roles in front of the offer definition. Moreover, there is a need concerning the organization of transversal work teams in $\mathrm{C} 1$ to redesign the offer of safety clothing, and new alliances must be considered in the external value chain in order to fulfill the criteria of the innovative value proposition of a PSS.

\section{Conclusions}

Innovating in business models depends highly on the firm context and the objectives to be achieved through the innovation initiatives. Both technology-push and demand-pull approaches interact in an interdependent way to trigger successful transformations within the business model. Furthermore, the demand-pull approach seems to be crucial to achieve a successful business model transformation, as it enables to consider a complex set of needs coming from customers, partners, public sector and society in a global sense. The case study shows that, in PSS context, the demand-pull approach leads to radical transformations of the entire business model, involving the internal value chain and the external value chain. Additionally, the case study reveals that the actors' needs go beyond economic interests and integrate sustainability aspects like the minimization 
of the water consumption and the improvement of the work conditions. This paper investigates the general impacts of demand-pull approach on business models innovation in one single case study. Certainly, more research is needed in different company contexts, taking into account aspects as culture, size, and domain of activity and maturity in the market. Conducting broader empirical research in this emerging topic contributes to have a complete vision about the impact of the demand-pull innovation approach in the business model transformation in B2B, regarding both customers' business models as well as providers' business models.

\section{Acknowledgments}

Auvergne Rhone-Alpes Region (France) supports this research through a doctoral thesis allocation, and the sponsors of this research conducted within the framework of the PEAK Cluster: THESAME, Funds F2I/UIMM, French Plan d'Investissement d'Avenir and its financial operator Caisse des Dépôts, the ACE project of PFA.

\section{References}

1. Vezzoli, C., Ceschin, F., Diehl, J.C., Kohtala, C.: New design challenges to widely implement "Sustainable Product-Service Systems.” J. Clean. Prod. 97, 1-12 (2015).

2. Chau, P.Y.K., Tam, K.Y.: Organizational adoption of open systems: a "technology-push, needpull"perspective. Inf. Manag. 37, 229-239 (2000).

3. Di Stefano, G., Gambardella, A., Verona, G.: Technology push and demand pull perspectives in innovation studies: Current findings and future research directions. Res. Policy 41, 1283-1295 (2012).

4. Rothwell, R.:Developments towards the fifth generation model of innovation. Technol. Anal. Strateg. Manag. 4, 73-75 (1992).

5. Van Lancker, J., Mondelaers, K., Wauters, E., Van Huylenbroeck, G.: The Organizational Innovation System: A systemic framework for radical innovation at the organizational level. Technovation 52-53, 40-50 (2016).

6. Tohidi, H., Jabbari, M.M.: Different Stages of Innovation Process. Procedia Technol. 1, 574-578 (2012).

7. Chesbrough, H.: Business Model Innovation: Opportunities and Barriers. Long Range Plann. 43, 354363 (2010).

8. Lüdeke- Freund, F.: Towards a Conceptual Framework of Business Models for Sustainability, in: Knowledge Collaboration \& Learning for Sustainable Innovation ERSCP-EMSU Conference, pp. 1-28, Delft, The Netherlands (2010).

9. Vargo, S.L., Maglio, P.P., Archpru, M., Akaka, M.A.: On value and value co-creation: A service systems and service logic perspective. Eur. Manag. J. 26, 145-152 (2008).

10. Antikainen, M., Valkokari, K.: A Framework for Sustainable Circular Business Model Innovation. Technol. Innov. Manag. Rev. 6, 5-12 (2016).

11. Boons, F., Lüdeke-Freund, F.: Business models for sustainable innovation: state-of-the-art and steps towards a research agenda. J. Clean. Prod. 45, 9-19 (2013).

12. Tukker, A., Emmert, S., Charter, M., Vezzoli, C., Sto, E., Munch Andersen, M., Geerken, T., Tischner, U., Lahlou, S.: Fostering change to sustainable consumption and production: an evidence based view. J. Clean. Prod. 16, 1218-1225 (2008).

13. Bocken, N.M.P., Short, S.W., Rana, P., Evans, S.: A literature and practice review to develop sustainable business model archetypes. J. Clean. Prod. 65, 42-56 (2014).

14. Rennings, K.: Redefining innovation - eco-innovation research and the contribution from ecological economics. Ecol. Econ. 32, 319-332 (2000).

15. Tukker, A.: Eight types of product-service system: eight ways to sustainability? Experiences from SusProNet. Bus. Strateg. Environ. 13, 246-260 (2004).

16. Orellano, M., Lambey-checchin, C., Medini, K., Neubert, G.: Towards an integration of lifecycle thinking into PSS business models, in: $10^{\text {th }}$ CIRP international conference in IPS2 on Procedia CIRP. pp. 29-31, Linköping, Sweden (2018). 